\title{
初中物理课堂教学渗透情感激励的策略分析
}

\author{
丁胜建
}

湖南省长沙市长沙县百熙实验学校初中部

DOI:10.32629/jief.v2i4.1249

[摘 要] 随着初中教育政策的不断深化和发展, 物理教学方式也发生了翻天覆地的变化, 情感激励这一教学方式渐渐走入了初中物理课堂, 促进学生建立自信心。情感激励方式不仅仅帮助学生获得满足感, 还让学生对物理产生浓厚兴趣。对于初中阶段的学生来说, 这一教学方式 令他们成为课堂的中心, 并从中获得学习的快乐。

[关键词] 初中物理; 课堂教学; 情感激励

中图分类号: G633.7 文献标识码: A

情感激励能为初中的物理课堂带来愉悦轻松的氛围, 让学生和教师 建立良好的关系。只有在一个舒适的环境下在善解人意的教师的带领下, 学生才会更愿意去深入学习物理, 才会对物理产生极大兴趣。初中物理 对于之前从未接触过的学生来说是一个难攻克的关卡, 所以非常需要教 师应用适当的教学方式带领他们探索物理世界。

\section{1 初中物理教学中情感激励的原则}

\section{1 科学性原则}

凡事都要讲究科学性, 不然的话课堂就会乱套, 学生根本无法从课 堂中学到知识。这就需要教师的情感激励策略具有层次性和逻辑性。具 有层次性是为了维护课堂的秩序, 情感激励不代表着毫无原则不讲科学 的激励, 而是要符合教育综合理念, 做到有层次, 有秩序。具有逻辑性 是因为学习物理需要严谨认真的学习态度, 因此教学方式更不能有半点 纰漏, 情感激励是一项新兴的教育方式, 这教学方式在物理教学的运用 中更是需要极为严谨的逻辑性, 根据学生的认知能力, 情境的不同和内 容的不同而做出相应的变化。

\section{2 情感性原则}

情感激励自然要遵循情感性原则。在教学过程中, 物理教师要以饱 满的热情以及充分的耐心, 对学生的关心等让学生体会到来自教师的善 意。处于初中这个阶段的孩子, 大多数比较爱面子, 自尊心极强, 这就 需要教师把握奖罚之间的度, 既能激励学生继续进步, 也避免学生自尊 心受损。因此, 教师在学生取得进步的时候或者积极表现的时候, 千万 不能文啬表扬, 要让学生感受到教师的夸赞, 激励他们继续努力; 在他 们犯错误的时候, 一定要耐下心来, 万万不能挖苦学生, 这只会让学生 越来越讨厌上物理课, 从此对物理失去兴趣。但需要注意的是, 表扬和 惩罚都要有一个度, 否则只会让学生越走越偏。

\section{3 目的性原则}

目的性原则中的 “目的” 简单来说也就是目标, 实行情感激励的目 标。在初中物理课堂中实行这一教学方式, 就是为了激励学生学习物理, 激发他们对物理的兴趣。但主要还是为了实现短期目标, 毕竟实现所有 短期目标之后, 长期目标也就不在话下了。情感激励遵循目的性原则, 可以让学生和教师为了短期目标一起努力, 最终实现教育的终极目标, 激发他们的热情, 在为目标的同时也提升了自己的物理水平。

\section{2 初中物理课堂教学渗透情感激励策略的途径}

\section{1 改变课堂氛围}

物理课堂是学生学习物理的主要场所, 教师在课堂上实行情感激励 是为了促进学生的学习, 提高学习效果。传统的教学方式忽略学生的主 体地位, 教师是整个课堂的主角, 教师将知识毫无保留争分夺秒地传授
给学生, 丝毫没有考虑过学生是否吸收, 这只会让课堂变得死气沉沉没 有生机。因此, 改变课堂氛围能让情感激励更好的在课堂上进行, 一个 良好活跃的课堂气氛会让学生更加投入轻松, 这样教师再通过情感激励, 就可以很好地将学生带入到课堂中去, 引导学生自己去思考去探索, 激 发学生学习物理的积极性, 让学习物理成为一件快乐的事情。

\section{2 举行与物理有关的活动}

物理课堂可以通过举办一些活动来使它变得丰富多彩。例如, 在课 堂上教师做一些物理实验, 学生通过观察实验来了解实验内容; 教师还 可以举办物理知识竞赛, 鼓励学生积极参加, 拓展学生们的视野等等。 学生在参加活动的同时也加强了和教师的沟通, 促进情感的交流。很多 学生之前不敢与教师有过多的交流, 对教师有恐惧感, 这对教师实行情 感激励是非常不利的, 因此教师可以通过举办活动拉近与学生的距离, 加深对学生的了解, 为渗透情感激励教学打下基础。在这些活动中, 教 师可以更好地走进学生的世界, 从而产生情感共鸣。要知道, 只有师生 关系变好了, 课堂教学才能更好进行, 效率才会不断提高。

2.3 转变教学方式

以往的教学方式多多少少存在一些问题和不足, 教师一定要及时的 转变教学方式, 进而提升学习效果。物理的基础主要是观察和实验还有 理论学习。对于之前没有接触过学生来说, 物理是比较难得, 学起来可 能会吃力, 这是教师千万不能心急, 一定要耐心地帮助学生巩固基础, 引导他们树立自信心。而且物理是一门注重逻辑思维能力的一门课, 依 靠死记硬背是学不长久的, 只会让学生对物理越来越没有兴趣, 所以教 师一定要转变教学方式, 在传授学生知识的基础上, 还要告诉学生正确 的学习方法, 引导学生如何高效学习物理, 而且一定要注重对学生的情 感激励, 避免学生产生一些消极情绪影响学习进度。

\section{3 结束语}

总而言之, 在进行物理教学的过程中, 会让学生收获到很多知识, 学习很多技能, 提升自身能力。但最关键的是, 要时刻关注学生的情绪, 将情感激励渗透到教学过程中, 引导学生一级极认真的态度去学习物理, 去探索物理的奥秘。作为教师, 不仅要传授给学生知识, 更要让学生感 受师生之间珍贵的情谊, 加深了解。

\section{[参考文献]}

[1]谢一杰.初中物理运用开放式教学的方法[J].新课程,2020(37):160.

[2]王耀龙.浅析如何有效提高初中物理教学效果 [J]. 新课 程,2020(37):180.

[3]周振龙.核心素养视角下初中物理高效课堂的构建 [J]. 文理导航 (中旬),2020(09):40+42. 